ORIGINAL ARTICLE, MEDICINE

\title{
The Role of Cytomegalovirus in Congenital and Early Postnatal Infections in Northeastern Bulgaria
}

\author{
Zhivka D. Stoykova ${ }^{1}$, Lilia I. Ivanova², Tatina T. Todorova ${ }^{3}$ \\ ${ }^{1}$ Department of Microbiology and Virology, Medical University of Varna, Department of Clinical Virology, St. Marina University \\ Hospital, Varna, Bulgaria \\ ${ }^{2}$ Laboratory of Virology, St. Marina University Hospital, Varna, Bulgaria \\ ${ }^{3}$ Department of Preclinical and Clinical Sciences, Faculty of Pharmacy, Medical University of Varna, Varna, Bulgaria
}

\section{Correspondence:}

Zhivka D. Stoykova, Department of Microbiology and Virology, Medical University of Varna, 3 Bregalniza Str., 9002 Varna; Department of Clinical Virology, St. Marina University Hospital, 1 Hristo Smirnenski Str., fl. 2, 9000 Varna, Bulgaria

E-mail: jivita77@abv.bg

Tel: +359888003553

Received: 12 Apr 2016

Accepted: 23 Jan 2017

Published Online: 18 Apr 2017

Published: 29 Sep 2017

Key words: CMV, human herpesvirus 5 , neonates, ELISA, seroepidemiologic studies

Citation: Stoykova ZD, Ivanova LI, Todorova, TT. The role of cytomegalovirus in congenital and early postnatal infections in Northeastern Bulgaria.

Folia Medica 2017;59(3):298-302. doi: 10.1515/folmed-2017-0036
Background: Human cytomegalovirus is a ubiquitous, large enveloped DNA $\beta$-herpesvirus that, like other herpesviruses, establishes lifelong latency following primary infection. It is the most frequent cause of congenital, neonatal and early postnatal infections with long lasting sequelae.

Aim: The aim of the present study was to assess the prevalence of cytomegalovirus among a cohort of newborns and 1-3-month-old children with neurological symptoms, physical retardation, prolonged jaundice, thrombocytopenic purpura and other disabilities.

Materials and methods: The study was a retrospective cross-sectional analysis of serological screening data for detection of specific anti-cytomegalovirus $\lg \mathrm{M}$ and IgG in children from Northeastern Bulgaria.

Results: Between 2003 and 2015, average prevalences of 18.8\% (95\% Cl: 15.4 to 22.2) for anti-CMV IgM antibodies (suggesting acute infection) and $84.7 \%$ (95\% Cl: 81.6 to 87.8 ) for anti-CMV IgG antibodies were measured in a total number of 517 samples. The prevalence rate of anti-CMV IgM in 1-3-month-old children was 4-fold higher than that in newborns [25.8\% (95\% Cl: 21.1 to 30.5$)$ and $6.4 \%(95 \%$ $\mathrm{Cl}: 2.9$ to 9.9 , respectively]. In contrast, no significant difference was found for antiCMV IgG positivity between newborns and 1-3-month-old infants (84\% and $85 \%$, respectively).

Conclusions: The data obtained strongly encourage screening of pregnant women for anti-CMV IgG and IgM to avoid transmission of the infection and severe complications of congenital infection.

\section{BACKGROUND}

Human cytomegalovirus (CMV) is a large enveloped DNA $\beta$-herpesvirus that, like other herpesviruses, establishes lifelong latency after the primary infection. ${ }^{1}$ Despite its ubiquity in the general population, most CMV infections are inapparent in healthy individuals.

CMV can be transmitted vertically and horizontally, and infections are classified as being acquired before birth (congenital), at the time of delivery (perinatal), or later in life (postnatal). ${ }^{1}$ The infection causes a wide range of severe disabilities in neonates and could be manifested as intrauterine growth retardation, jaundice, hepatosplenomegaly, thrombocytopenic purpura, myocarditis, pneumonitis, central nervous system abnormalities or chorioretinitis.

As the virus remains in latency after the primary contamination and reactivates periodically, congenital CMV infection may follow either primary or recurrent infection of mother. ${ }^{2}$ Primary CMV infections are more likely to cause damages as they are transmitted more frequently to the fetus ${ }^{3}$, but the correlation between newborn disease severity and the type of mother's infection (primarily or not primarily) still remains unclear. ${ }^{4}$ The time of maternal primary infection is also important and earlier pregnancy infections are associated with worse outcome..$^{3,5}$ The birth prevalence of congenital CMV infection is estimated to be $0.64 \%$, but it varies considerably among different study populations. ${ }^{3}$ The permanent neurological and neurodevelopmental sequelae is as high as $60 \%$ in infants with symptoms at birth and even infants without symptoms at birth will have sequelae in up to $13.5 \%$ of cases, most commonly manifested as sensorineural hearing loss. ${ }^{6}$ 


\section{AIM}

Little is known about the infant seroprevalence and the relative deal of CMV in congenital and early postnatal disorders in Bulgaria as national and regional trends in CMV infection have not been examined recently. Universal screening during pregnancy does not exist (as in most of the countries) and it is difficult to recognize primary CMV infection in newborns and babies. With the present study we aim to assess the relative deal of CMV in congenital and early postnatal infections in selected group of children with undefined cause of different disorders after birth. We also try to determine the possibility of early age acquisition of CMV infection in North-Eastern Bulgaria.

\section{MATERIALS AND METHODS}

From January 2003 to December 2015, a total of 517 children (187 newborns and 330 1-3-monthold children) with neurological symptoms, physical retardation, prolonged jaundice, thrombocytopenic purpura and other disabilities were studied in single serum samples. For clinical purposes, the diagnosis was based primarily on serological screening data.

Commercial ELISA test kits for detection of specific anti-CMV IgM and IgG antibodies (EUROIMMUN - Germany, VIRCELL - Spain, Dia Pro - Italy, Adaltis - Italy) were performed according to manufacturer's recommendations. Anti-CMV IgM positive samples were considered as recent infections.

The proportion of CMV seropositive infants and their corresponding confidence intervals, chi-squared distributions and p-values were calculated with McCallum Layton calculators (www.mccallum-layton. co.uk) and Social Science Statistics (www.socscistatistics.com). $\mathrm{P}<0.05$ was considered significant for all statistical tests.

\section{RESULTS}

From a total of 517 symptomatic children investigated, 97 (18.8\%, 95\% CI: 15.4 to 22.2$)$ were antiCMV IgM positive and 420 (81.2\%, 95\% CI: 77.8 to 84.5 ) were anti-CMV IgM negative (Table 1). Respectively, 438 (84.7\%, 95\% CI: 81.6 to 87.8$)$ were anti-CMV IgG positive and 79 (15.3\%, 95\% CI: 12.2 to 18.4 ) were anti-CMV IgG negative. Out of anti-CMV IgM positive children, 91 were antiCMV IgG positive too ( $17.6 \%$ of the total, $95 \% \mathrm{CI}$ : 14.3 to 20.9 ), while out of anti-CMV IgM negative children, 347 (67.1\%, 95\% CI: 63.1 to 71.2$)$ were anti-CMV IgG positive (Table 1).
In the group of newborns (aged $<1$ month), twelve babies (6.4\%, 95\% CI: 2.9 to 9.9$)$ were antiCMV IgM positive (Table 2), while in the group of 1-3-month-old children, 85 (25.8\%, 95\% CI: 21.1 to 30.5) were anti-CMV IgM positive (Table 3). The risk ratio (1-3-month-old children versus newborns) is 4.0 and after accounting for sampling variability, the age could be considered to increase the risk of recent CMV infection after birth from 2.2 to 7.1 times (chi-square $=29.3 ; \mathrm{p}<0.05$ ). In contrast, no significant difference was found for anti-CMV IgG positivity between newborns and 1-3-month-old infants $-84 \%$ and $85 \%$, respectively (chi-square $=$ $0.1 ; \mathrm{p}=0.7)$.

Ten of 12 anti-CMV IgM positive newborns were anti-CMV IgG positive too $(5.3 \%, 95 \% \mathrm{CI}$ : 2.1 to 8.5 ), while anti-CMV IgG negative were only $2(1.1 \%, 95 \%$ CI: 0.4 to 2.6$)$ of the IgM positive newborns (Table 2). In the group of 1-3-month-old children, $81(24.5 \%, 95 \%$ CI: 19.9 to 29.1$)$ were positive for both anti-CMV IgM and anti-CMV IgG and $4(1.2 \%, 95 \% \mathrm{CI}: 0.03$ to 2.4$)$ were anti-CMV IgG negative and anti-CMV IgM positive (Table 3).

\section{DISCUSSION}

Transmission of CMV occurs from person to person through body fluids and viral particles can be found in blood, urine, semen, cervical secretion, saliva, breast milk and transplanted organs. ${ }^{1,7}$ The presence of specific anti-CMV IgG is indicative for an accomplished infection. The seroprevalence rate varies in different population and regions, and usually increases with age. According to previous studies in Northeastern Bulgaria, about $85 \%$ of the people over 15 years of age are CMV infected, including women of childbearing age. ${ }^{8}$ Similar seroprevalence rates were found in other European countries. ${ }^{9,10}$ In accordance, $84.7 \%$ of the children investigated in our study were anti-CMV IgG positive (suggesting a passive transmission of anti-CMV IgG antibody only).

Almost $19 \%$ of the tested children in the present study were found to be anti-CMV IgM positive, indicative for recent CMV infection. Primary infection during pregnancy could lead to intrauterine transmission, although a transmission in previously seropositive women due to reactivation or reinfection is the major route. ${ }^{2,9,10} \mathrm{CMV}$ is the most common cause of congenital infection in newborns with a reported incidence of $0.2-2.5 \%{ }^{11}$ and is usually asymptomatic at birth but with cumulative effect on morbidity and mortality. ${ }^{12}$ Symptomatic infants 
Table 1. Seroprevalence of CMV in children aged 0-3 months $(n=517)$

\begin{tabular}{ccc}
\hline & Number & Proportion \\
\hline IgM+ IgG- & 6 & $1.2 \%(95 \%$ CI: $0.3-2.1)$ \\
IgM+ IgG+ & 91 & $17.6 \%(95 \%$ CI: $14.3-20.9)$ \\
IgM- IgG+ & 347 & $67.1 \%(95 \%$ CI: $63.1-71.2)$ \\
IgM- IgG- & 73 & $14.1 \%(95 \%$ CI: $11.1-17.1)$ \\
\hline
\end{tabular}

Table 2. Seroprevalence of CMV in newborns $0-1$ month $(n=187)$

\begin{tabular}{ccc}
\hline & Number & Proportion \\
\hline IgM+ IgG- & 2 & $1.1 \%(95 \%$ CI: $0.4-2.6)$ \\
IgM+ IgG+ & 10 & $5.3 \%(95 \%$ CI: $2.1-8.5)$ \\
IgM- IgG+ & 147 & $78.6 \%(95 \%$ CI: $72.7-85.4)$ \\
IgM- IgG- & 28 & $15 \%(95 \%$ CI: $9.9-20.1)$ \\
\hline
\end{tabular}

Table 3. Seroprevalence of CMV in children 1-3 months old $(n=330)$

\begin{tabular}{ccc}
\hline & Number & Proportion \\
\hline IgM+ IgG- & 4 & $1.2 \%(95 \%$ CI: $0.03-2.4)$ \\
IgM+ IgG+ & 81 & $24.5 \%(95 \%$ CI: $19.9-29.1)$ \\
IgM- IgG+ & 200 & $60.6 \%(95 \%$ CI: $55.3-65.9)$ \\
IgM- IgG- & 45 & $13.6 \%(95 \%$ CI: $9.9-17.3)$ \\
\hline
\end{tabular}

identified at newborn screening generally have milder disorders than those referred for follow-up studies based on clinical abnormalities at birth. Prospective studies have shown that approximately half of the children born with symptomatic infection will develop sequelae. ${ }^{4}$ Our data reveal that $6.4 \%$ of newborns with consistent clinical symptoms have antiCMV IgM positivity, probably indicating congenital infection. According to other study, symptoms were present in $11 \%$ of CMV infected neonates and $42 \%$ of them had sequelae. ${ }^{13}$ A study in Brazil confirmed congenital CMV infection in $1.08 \%$ of the screened newborns. ${ }^{14}$ Previous study in our region showed frequency of $1.1 \%$ in randomly chosen newborns ${ }^{15}$, while frequency among European countries was found to vary between $0.18 \%-0.48 \%{ }^{9,16}$. Infants with symptomatic congenital CMV infection, identified on the base of clinical representation, have more frequent and severe disease at birth and more serious sequelae. ${ }^{17}$

The investigated symptomatic 1-3 month-old chil- dren were suspicious for intranatal or early postnatal infection and their positivity was $25.7 \%$ - a 4 -fold higher seroprevalence rate when compared with this of newborns. To existing data most of the term-born infants with perinatal infection are asymptomatic, because of maternal-transmitted CMV IgG antibody. In contrast, $15 \%-20 \%$ of infected preterm infants may develop clinical disease. ${ }^{18}$

Finally, we should like to point out one of the limitations of our study - CMV infection was diagnosed based on consistent clinical symptoms and presence of specific anti-CMV IgM in the patient's serum. Although the strong positive anti-CMV IgM immune response may be useful for finding suggested infection, serologic reactions are not recommended for diagnosis of CMV infection in neonates because they have sometimes both false positive and false negative results. ${ }^{7}$ According to our observation, in symptomatic children, the serological testing is the first predicting sign to examine virus excretion in urine or viral load in plasma. Testing with PCR 
techniques after positive serological screening results will be our future objective for better diagnosis.

Screening of pregnant women for CMV infection is not a routine practice in Bulgaria, but the data obtained strongly encourage screening for anti-CMV IgG and IgM among pregnant women to avoid transmission of the infection and severe complications of congenital infection.

\section{REFERENCES}

1. Mocarski E, Shenk T, Pass R. Cytomegalovirus. In: Knipe D, Howley P, editors. Fields Virology. Philadelphia: Lippincott Williams and Wilkins; 2007:2701-72.

2. Boppana SB, Rivera LB, Fowler KB, et al. Intrauterine transmission of cytomegalovirus to infants of women with preconceptional immunity. N Engl J Med 2001;344(18):1366-71.

3. Kenneson A, Cannon MJ. Review and meta-analysis of the epidemiology of congenital cytomegalovirus (CMV) infection. Rev Med Virol 2007;17(4):253-76.

4. Boppana SB, Ross SA, Fowler KB. Congenital cytomegalovirus infection: clinical outcome. Clin Infect Dis 2013;57(Suppl. 4):178-81.

5. Demmler GJ. Infectious Diseases Society of America and Centers for Disease Control. Summary of a workshop on surveillance for congenital cytomegalovirus disease. Rev Infect Dis 1991;13(2):315-29.

6. Swanson EC, Schleiss MR. Congenital cytomegalovirus infection: new prospects for prevention and therapy. Pediatr Clin North Am 2013;60(2):335-49.

7. Revello MG, Zavattoni M, Baldanti F, et al. Diagnostic and prognostic value of human cytomegalovirus load and IgM antibody in blood of congenitally infected newborns. J Clin Virol 1999;14(1):57-66.

8. Ivanova L. Herpes virus infections in human population in northeastern Bulgaria. Scr Sci Medica 2007;39(2):125.
9. Barbi M, Binda S, Caroppo S, et al. Multicity Italian study of congenital cytomegalovirus infection. Pediatr Infect Dis J 2006;25(2):156-9.

10. Vries JJC de, Zwet EW van, Dekker FW, et al. The apparent paradox of maternal seropositivity as a risk factor for congenital cytomegalovirus infection:a population-based prediction model. Rev Med Virol 2013;23(4):241-9.

11. Boppana SB, Ross SA, Shimamura M, et al. Saliva polymerase-chain-reaction assay for cytomegalovirus screening in newborns. N Engl J Med 2011;364(22):2111-8.

12. Bristow BN, O'Keefe KA, Shafir SC, et al. Congenital cytomegalovirus mortality in the United States, 1990-2006. PLoS Negl Trop Dis 2011;5(4):e1140.

13. Townsend CL, Forsgren M, Ahlfors K, et al. Longterm outcomes of congenital cytomegalovirus infection in Sweden and the United Kingdom. Clin Infect Dis 2013;56(9):1232-9.

14. Mussi-Pinhata MM, Yamamoto AY, Moura Brito RM, et al. Birth prevalence and natural history of congenital cytomegalovirus infection in a highly seroimmune population. Clin Infect Dis 2009;49(4):522-8.

15. Ivanova L, Vasileva P, Skochev $S$, et al. Newborn screening for congenital cytomegalovirus infection. Infectology 1996;xxxii(1):13-5.

16. Halwachs-Baumann G, Genser B, Danda M, et al. Screening and diagnosis of congenital cytomegalovirus infection: a 5-y study. Scand J Infect Dis 2000;32(2):137-42.

17. Dreher AM, Arora N, Fowler KB, et al. Spectrum of disease and outcome in children with symptomatic congenital cytomegalovirus infection. J Pediatr 2014;164(4):855-9.

18. Stehel EK, Sanchez PJ. Cytomegalovirus infection in the fetus and neonate. Neoreviews 2005;6(1):e38-45. 


\title{
Роль цитомегаловируса при врождённых и ранних послеродовых инфекциях в Северо-Восточной Болгарии
}

\author{
Живка Д. Стойкова' ${ }^{1}$ Лилия И. Иванова², Татина Т. Тодорова ${ }^{3}$ \\ ${ }^{1}$ Кафедра микробиологии и вирусологии, Медицинский университет- Варна, Кафедра клинической вирусологии, \\ УМБАЛ „Св. Марина“, Варна, Болгария \\ ${ }^{2}$ Вирусологическая лаборатория, УМБАЛ „Св. Марина“, Варна, Болгария \\ ${ }^{3}$ Кафедра доклинических и клинических исследований, Факультет фармации, Медицинский университет- Варна, Варна, \\ Болгария
}

\begin{abstract}
Адрес для корреспонденции: Живка Д. Стойкова, Кафедра микробиологии и вирусологии, Медицинский университет

- Варна, ул.„Брегалница“

3, 9002 Варна; Кафедра клинической вирусологии, УМБАЛ „Св. Марина“, ул.,„Христо Смирненски“ 1, эт. 2, 9000 Варна, Болгария

E-mail: jivita77@abv.bg

Тел: +359888003553
\end{abstract}

Дата получения: 12 апреля 2016

Дата приемки: 23 января 2017 Дата онлайн публикации: 18 апреля 2017

Дата публикации: 29 сентября 2017

Ключевые слова: ЦМВ, человеческий герпесвирус типа 5, новорожденные, ELISA, сероэпидемиологические исследования

\section{Образец цитирования:}

Stoykova ZD, Ivanova LI, Todorova, TT. The role of cytomegalovirus in congenital and early postnatal infections in Northeastern Bulgaria.

Folia Medica 2017;59(3):298-302. doi: 10.1515/folmed-2017-0036
Введение: Человеческий цитомегаловирус представляет собой повсеместно распространённый большой с ДНК оболочкой $\beta$-герпесвирус, который, подобно другим герпесвирусам, приобретает пожизненную латентность после первичной инфекции. Он является наиболее часто встречающейся причиной врождённых, неонатальных и ранних постнатальных инфекций с долговременными последствиями.

Цель: Целью настоящего исследования является выработка оценки распространения цитомегаловируса среди группы новорожденных и детей в возрасте от 1 до 3 месяцев с неврологическими симптомами, отставанием в физическом развитии, длительной желтухой, тромбоцитопенической пурпурой и другими отклонениями.

Методы: Исследование представляет собой ретроспективный перекрёстный анализ данных серологического скрининга с целью установления конкретных анти-цитомегаловирусных $\lg$ и и $\lg$ с среди детей в Северо-Восточной Болгарии.

Результаты: За время периода 2003-2015 было измерено среднее распространение в рамках 18.8\% (95\% Cl: 15.4 до 22.2) анти-ЦМВ антител класса IgM (предполагающие острую инфекцию) и 84.7\% (95\% CІ: 81.6 до 87.8) анти-ЦМВ антител класса IgG общим числом в 517 проб. Преобладающая частота анти-ЦМВ антител класса IgM среди детей в возрасте 1-3 месяцев была в четыре раза выше по сравнению с новорожденными и составляла 25.8\% (95\% Cl: 21.1 до 30.5) против 6.4\% (95\% Cl: 2.9 до 9.9). В отличие от данных результатов не была установлена значительная разница в положительных результатах анти-ЦМВ класса IgG среди новорожденных и младенцев в возрасте 1-3 месяцев - соответственно $84 \%$ и $85 \%$.

Заключение: На основании полученных результатов нами настоятельно рекомендуется проведение скрининга анти-ЦМВ класса IgG и IgМ для беременных женщин с целью избежать передачу инфекции и тяжёлых осложнений после врождённой инфекции. 